\begin{tabular}{|l|l|l||}
\hline \multicolumn{2}{|c|}{ PublisherInfo } \\
\hline \hline PublisherName & $:$ & BioMed Central \\
\hline \hline PublisherLocation & $:$ & London \\
\hline \hline PublisherImprintName & $:$ & BioMed Central \\
\hline \hline
\end{tabular}

\title{
Articles selected from Faculty of 1000 in September 2003
}

\begin{tabular}{|l|l|l||}
\hline \multicolumn{2}{|c|}{ ArticleInfo } \\
\hline \hline ArticleID & $:$ & 659 \\
\hline \hline ArticleDOI & $:$ & $10.1186 /$ bcr659 \\
\hline \hline ArticleCitationID & $:$ & E11 \\
\hline \hline ArticleSequenceNumber & $:$ & 23 \\
\hline \hline ArticleCategory & $:$ & Article selection \\
\hline \hline ArticleFirstPage & $:$ & 1 \\
\hline \hline ArticleLastPage & $:$ & 2 \\
\hline \hline & & RegistrationDate : 2003-9-26 \\
\hline ArticleHistory & $:$ & OnlineDate \\
\hline \hline ArticleCopyright & $:$ & BioMed Central Ltd2003-9-26 \\
\hline \hline ArticleGrants & $:$ & \\
\hline \hline ArticleContext & $:$ & 130585555 \\
\hline \hline
\end{tabular}


Valerie Speirs, Aff1

Corresponding Affiliation: Aff1

Email: v.speirs@leeds.ac.uk

Aff1 Molecular Medicine Unit, University of Leeds, St James's University Hospital, Leeds LS9 7TF, UK

\section{Articles selected from Faculty of 1000}

\section{References}

1. Kang Y, Siegel PM, Shu W, Drobnjak M, Kakonen SM, Cordón-Cardo C, Guise TA, Massagué J: A multigenic program mediating breast cancer metastasis to bone. Cancer Cell. 2003, 3: 537-549. For the Faculty of 1000 evaluation of this article please see http://breast-cancer-research.com/reports/ bcr659.asp\#kang

2. Primiano T, Baig M, Maliyekkel A, Chang BD, Fellars S, Sadhu J, Axenovich SA, Holzmayer TA, Roninson IB: Identification of potential anticancer drug targets through the selection of growthinhibitory genetic suppressor elements. Cancer Cell. 2003, 4: 41-53. For the Faculty of 1000 evaluation of this article please see http://breast-cancer-research.com/reports/bcr659.asp\#primiano

3. Schmidt-Kittler O, Ragg T, Daskalakis A, Granzow M, Ahr A, Blankenstein TJ, Kaufmann M, Diebold J, Arnholdt H, Muller P, Bischoff J, Harich D, Schlimok G, Riethmuller G, Eils R, Klein CA: From latent disseminated cells to overt metastasis: genetic analysis of systemic breast cancer progression. Proc Natl Acad Sci U S A. 2003, 100: 7737-7742. For the Faculty of 1000 evaluation of this article please see http://breast-cancer-research.com/reports/bcr659.asp\#schmidt-kittler

4. Varnum SM, Covington CC, Woodbury RL, Petritis K, Kangas LJ, Abdullah MS, Pounds JG, Smith RD, Zangar RC: Proteomic characterization of nipple aspirate fluid: identification of potential biomarkers of breast cancer. Breast Cancer Res Treat. 2003, 80: 87-97. For the Faculty of 1000 evaluation of this article please see http://breast-cancer-research.com/reports/bcr659.asp\#varnum

This PDF file was created after publication. 